\title{
高周波キャリア型薄膜磁界センサの 位相差検出による交流磁界測定装置の開発
}

\author{
Development of an AC Magnetic Field Measurement System Using Phase Difference Detection \\ of a High-Frequency-Carrier Magnetic Field Sensor
}

\author{
小澤哲也・馬渡宏・藪上信・石山和志・荒井賢一 \\ 東北大学電気通信研究所，仙台市青葉区片平 2-1-1（干980-8577）
}

T. Ozawa, H. Mawatari, S. Yabukami, K. Ishiyama, and K. I. Arai

Research Institute of Electrical Communication, Tohoku University, 2-1-1 Katahira, Aoba-ku, Sendai 980-8577, Japan

\begin{abstract}
The impedance and phase characteristic of a magnetic thin film changes when a magnetic field is applied. The high-frequency-carrier magnetic field sensor, also called a GMI sensor, employs this phenomenon as its principle. We directed our attention to the change in the phase characteristic, and measured the dc magnetic field by measuring the phase as a phase difference, using the dual-mixer time-difference method. We optimized the method and the continuous sampling condition to measure the phase difference, and developed an efficient system for measuring the continuous sampling phase difference with low noise. The system was successfully used to measure the ac magnetic field by continuous sampling of the phase difference of a high-frequency-carrier magnetic field sensor.
\end{abstract}

Key words: magneto-impedance, magnetic thin film, dual-mixer time-difference (DMTD), phase difference, high-frequency-carrier thin-film magnetic field sensor, jitter, time interval analyzer

\section{1. はじめに}

磁性薄膜に磁界が加えられると磁性薄膜のインピーダンスが変 化する現象，いわゆる磁気インピーダンス効果が生じる. 高周波 キャリア型薄膜磁界センサ(磁気インピーダンスセンサ)は, 磁性薄 膜に高周波キャリアを通電することにより，そのインピーダンス の変化量を促進して検出することを原理としたセンサであり, 高 感度な磁界センサとして応用できる，また，センサ自体の形状が 簡単であるので, 容易に薄膜化しやすく, 高密度に配置すること が可能であり，その結果，高い空間分解能を得ることができるの で，脳磁界などの生体磁界情報の測定などに応用が期待される. われわれは高周波キャリアを通電している磁性薄膜センサに対し て，交流磁界が加えられたことで発生するインピーダンスの変化 を利用した振幅変調をスペクトラムアナライザで測定することに より, 高感度磁気センサとしての評価を報告してきた ${ }^{12)}$. しかし, この振幅変調方式は高周波キャリアの信号源が持つ位相ノイズの 影響により低周波の交流磁界における振幅変調成分を検出できな くなる問題があり, 直流磁界の変化や脳磁界測定に向けた $1 \mathrm{kHz}$ 程度の低周波磁界变化の測定が困難である. そこで，われわれは 高周波キャリア型薄膜磁界センサのインピーダンス変化に伴って 生じる位相成分の変化に着目して，センサを通して位相変化の影 響を受けたキャリアとセンサを通していないキャリアとの間に生 じる位相差を DMTD (Dual-Mixer Time-Difference) 法 ${ }^{344)}$ とタイ
ムインターバルカウンタを用いることにより時間差として測定す ることで, 磁界測定感度の評価を行ない報告してきた ${ }^{5)}$. しかし, この報告で使用したタイムインターバルカウンタは, 位相差を連 続サンプリングできず，また最もシステムノイズを抑えられる最 適な条件下でDMTD 方法が行なわれていなかったために, 測定結 果は平均值として取り扱わなければならず，結果として測定でき る磁界の情報は直流磁界だけに限定されてしまう問題があった。 本論文では, 1 周期毎に連続サンプリングが可能なタイムインター バルアナライザを導入して, なおかつ平均化処理なしで高分解能 で位相差の連続サンプリングが可能な DMTD の条件を検討した. その結果, 高周波キャリア型薄膜磁界センサに磁界が加えられた ときの位相差変化を高分解能で連続サンプリングすることが可能 になり, 位相差測定方法では初めて交流磁界が測定可能となった ことを報告する.

\section{DMTD による位相差測定の原理}

高周波キャリア型薄膜磁界センサのインピーダンス変化を原理 とした振幅変調方式で用いられているキャリアの周波数は $400 \mathrm{MHz}$ 程度であるので, 位相差測定方法に対しても使用するキ ヤリアは同帯域を使用することが予想される. 一方, 位相差測定 による磁界測定分解能は, 位相差測定の分解能に依存寸るので, 可能な限り高精度で位相差測定を行なう必要があるが，このよう な高周波の位相差測定は, 周期が短いために位相差に相当する時 間の差は, 非常に小さく, 測定が困難である. 本論文では, 高周 波キャリア型薄膜センサを通過した後の高周波キャリアとセンサ を通していない高周波キャリアを低周波にダウンコンバートして, 周期を長く引き伸ばし, 時間差に相当する位相差を高精度で測定 するDMTD 方法を採用している.

DMTD 方法を採用した実験回路の概略図を Fig. 1 に示す. ミキ サはRF (Radio Frequency) port と LO (Local Oscillator) port の 入力端子と IF (Intermediate Frequency) port の出力端子から構 成されているダブル バランスドタイプ (R\&K M6CA)を用いた. RF 信号源 (Agilent Technology 8664A) から生成されたキャリア は 3 抵抗パワースプリッタで 2 分割されて, 一方のキャリアはセ ンサを通過させており，もう一方のキャリアは位相調整用の移相 器を通過させた後, 双方のキャリアは個々のミキサの RF portに 接続される. また, LO 信号源 (Agilent Technology 8648B) の出 力も, 3 抵抗パワースプリッタで 2 分割されて, 個々のミキサの LO port に入力される. 入力された RF 信号と LO 信号によりミキ 


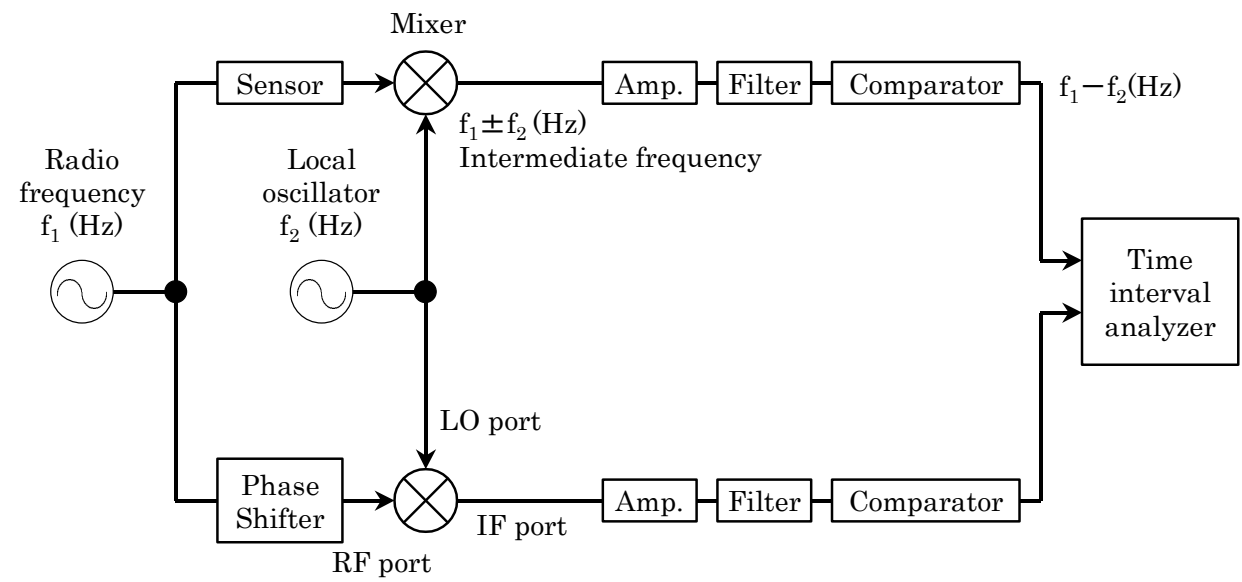

Fig. 1 Dual-mixer time-difference system.

サは, $f_{\mathrm{IF}}=\left|n \times f_{\mathrm{RF}} \pm m \times f_{\mathrm{LO}}\right|$ の信号 $(m$ と $n$ は任意の正の整数 $)$ を $\mathrm{IF}$ 信号として出力する. ここで必要な周波数は $f_{\mathrm{RF}}-f_{\mathrm{LO}}$ 周波数 成分のみであるので, $f_{\mathrm{RF}}-f_{\mathrm{LO}}$ 周波数成分を通過帯域とする周波 数可変のフィルタを接続している，その前段にあるアンプは減衰 した IF 信号を増幅するために用いている. また，バンドパスフィ ルタを通過した信号は正弦波であり，時間差測定に適した矩形波 ではない，そこで，フィルタ通過後の信号は，コンパレータを使 用することで，正弦波をTTL信号に変換している，そして，高周 波キャリア型薄膜磁界センサを通過していない信号と通過した信 号の時間差をタイムインターバルアナライザ (横河電機 TA720) で連続サンプリングして，位相差を求める方法とした．また，全 ての機器は, 装置間の時間確度を向上させるためにキャリア信号 源の内部基準クロック $10 \mathrm{MHz}$ でフェーズロックさせている.

\section{3. 位相差測定条件の最適化の検証}

\section{1 タイムインターバルアナライザの内部ジッタエラーによる位 相差測定分解能への影響}

DMTD 方法を適用すると, 位相情報は保持されながら低 周波に変換されるために, 時間差測定の分解能が改善されて磁界 測定の分解能が向上する. しかし，実際にはタイムインターバ ルアナライザ固有の時間差測定誤差の内部ジッタエラーが 存在するので, この内部ジッタエラーが時間差測定の分解 能であり位相差測定の分解能が決定する. そこで, タイム インターバルアナライザの有する内部ジッタエラーが位相 差測定分解能に与える影響を検討した. DMTD 方法におい て位相差を測定する IF 信号の周波数を $f_{\mathrm{IF}}$ とすると, 内部 ジッタエラー $T_{\text {int-jitter }}\left(\mathrm{sec}_{\mathrm{rms}}\right)$ による位相差測定分解能 $\phi_{\text {int-jitter }}\left(\operatorname{deg}_{\mathrm{rms}}\right)$ は, 次式で求められる.

$$
\phi_{\text {int-jitter }}=360 \cdot f_{\mathrm{IF}} \cdot T_{\text {int-jitter }}
$$

この(1)式に使用するタイムインターバルアナライザの 仕様上の内部ジッタエラー $100 \mathrm{ps}_{\mathrm{rms}}$ を代入して求められ た位相差ジッタエラーを Fig. 2 に示す.

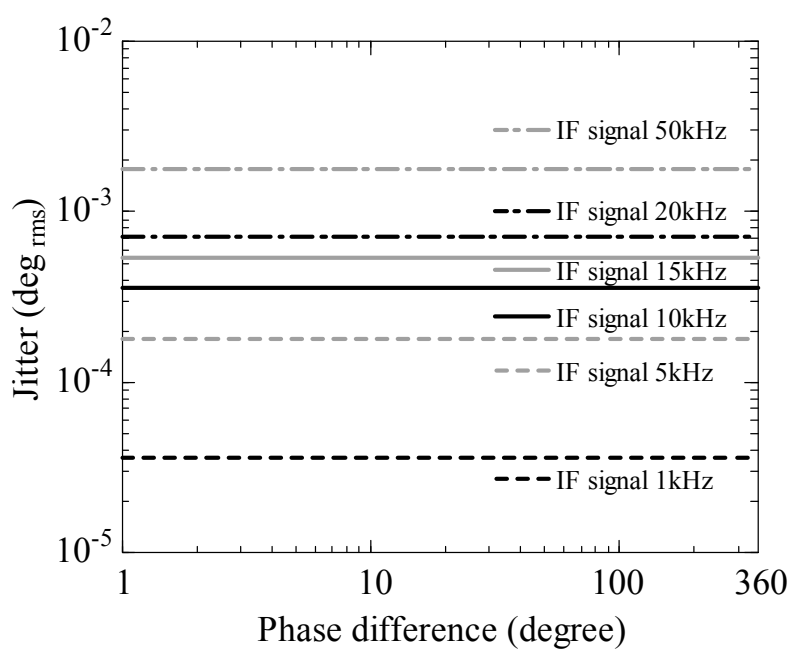

Fig. 2 Phase difference jitter error calculated from the internal jitter error of the Time Interval Analyzer.

タイムインターバルアナライザを用いて, 高周波の位相差情報 と低周波の位相差情報を測定したときの測定分解能を比較すると， 双方の位相情報が同じ值であっても，位相差を時間差に換 算すると, 高周波における時間差の方が短く, 時間差測定 分解能が不足するので, 位相差測定の分解能は低下寸るこ とがわかる，そのために，できるだけ低周波に変換すれば位相差 測定の分解能が改善されて磁界測定の分解能が向上寸ることにな る.しかし, 実際には極端に低周波一変換すると, 位相差測定は 1 周期毎に行なわれるので, サンプリングレートが低下して交流磁 界の測定が不可能になる問題が生じる.

\section{2 信号源固有の周波数ジッタによる位相差測定分解能への影響}

実際の $\mathrm{RF}$ 信号の周波数 $f_{\mathrm{RF}}$ と $\mathrm{LO}$ 信号の周波数 $f_{\mathrm{LO}}$ は, $\mathrm{RF}$ 信 号源の内部基準クロックにより LO 信号源をフェーズロックして いても, RF 信号源の内部で常時わずかに変動する周波数ジッタが 存在する. その結果, $\mathrm{RF}$ 信号源と LO信号源には個々の周波数ジ ッタを有することになる. 個々の信号源の周波数ジッタが多い場 合, ミキサで生成される IF 信号にも多くの周波数ジッタが含まれ 
る結果となり，位相差測定時の位相差ジッタエラーが増加する原 因となる.

そこで，使用する RF 信号と LO 信号が有する周波数ジッタの 特性を測定して，ミキサで生成される IF 信号の周波数ジッタの予 測を行なった。 そして，IF 信号の周波数ジッタの影響で発生する 位相差ジッタエラーを予測した。測定は，ユニバーサルカウンタ (Stanford Research Systems SR620)を使用して, GATE 幅 $1 \mathrm{sec}$ として双方の信号源の出力信号 $(14 \mathrm{dBm})$ の立ち上がりの数を力 ウントして周波数とした.

RF信号とLO信号の周波数ジッタの測定結果をFig. 3 に示す. 双方の信号には周波数ジッタが確認されるが，ほとんど一致して いるので, 双方の信号源は確実にフェーズロックされていること がわかる. ここで $f_{\mathrm{RF}}-f_{\mathrm{LO}}$ 周波数成分以外の不要な周波数成分を 発生しない理想的なミキサを使用したと仮定したとき，双方の信 号源固有の周波数ジッタがミキサで生成されるIF信号の周波数ジ ッタとして与える影響は，次式で表現できる.

$$
f_{\mathrm{IF}-\mathrm{jitter}}=\left(f_{\mathrm{RF}-\mathrm{jitter}}^{2}+f_{\mathrm{LO}-\mathrm{jitter}}{ }^{2}\right)^{1 / 2}
$$

ここで, $f_{\mathrm{IF-jitter}}\left(\mathrm{Hz}_{\mathrm{rms}}\right)$ は IF 信号の周波数ジッタ, $f_{\mathrm{RF}-\mathrm{jitter}}\left(\mathrm{Hz}_{\mathrm{rms}}\right)$ は RF 信号の周波数ジッタ, $f_{\mathrm{LO}-\mathrm{jitter}}\left(\mathrm{Hz}_{\mathrm{rms}}\right)$ は LO 信号の周波数ジ ッタである. 但し，この表現では，周波数ジッタは測定に使用し た GATE 幅 $1 \mathrm{sec}$ で平均化されているので，位相差ジッタエラー の予測計算を行なうには, IF 信号の 1 周期毎の周波数ジッタに換 算しなければならない. GATE 幅 1 sec の周波数ジッタを IF 信号 の 1 周期毎の周波数ジッタに換算する場合は，算出平均における 確率誤差を考慮した次式を使用する.

$$
f_{\mathrm{IF}-\mathrm{jitter}}=\left(f_{\mathrm{RF}-\mathrm{jitter}}{ }^{2}+f_{\mathrm{LO}-\mathrm{jitter}}{ }^{2}\right)^{1 / 2} \cdot f_{\mathrm{IF}}{ }^{1 / 2}
$$

ここで， $f_{\mathrm{IF}}(\mathrm{Hz})$ は IF 信号の周波数である. 求めた $\mathrm{IF}$ 信号の周 波数ジッタから，位相差ジッタエラーは次式で計算できる.

$$
\phi_{\mathrm{IF}-\mathrm{jitter}}=360 \cdot\left(f_{\mathrm{IF}-\mathrm{jitter}} / f_{\mathrm{IF}}\right)
$$

ここで, $\phi_{\text {IF-jitter }}\left(\operatorname{deg}_{\mathrm{rms}}\right)$ は IF 信号に発生する位相差ジッタエラ 一となる. 求めた位相差ジッタエラー $\phi_{\mathrm{IF}-\mathrm{jitter}}$ は, 1 周期毎にどれ だけの位相差ジッタエラーが生じるかの指標であるので，位相差 が $180 \mathrm{deg}$ であるときの位相差ジッタエラーは半分の值を取るこ とになる. この点を考慮して，RF信号の周波数を $500 \mathrm{MHz}$ 固定 の条件で IF 信号の周波数を変化させた場合に予想される位相差位相差ジッタエラーの関係を Fig. 4 に示す.

ミキサで混合させて生成される IF信号の周波数 $f_{\mathrm{IF}}$ が低い場合, 位相差ジッタエラーが多く含まれる結果となった。 これは IF信号 として $f_{\mathrm{RF}}-f_{\mathrm{LO}}$ 周波数成分以外の不要な周波数成分を発生しない 理想的なミキサを使用した場合，IF信号の周波数 $f_{\mathrm{IF}}$ は $f_{\mathrm{RF}}-f_{\mathrm{LO}}$ で表されるが, 実際のRF信号の周波数 $f_{\mathrm{RF}}$ と $\mathrm{LO}$ 信号の周波数 $f_{\mathrm{LO}}$ には各々周波数ジッタが含まれているので， $f_{\mathrm{IF}}$ を小さく設定する と， $f_{\mathrm{IF}}$ に対して信号源が持つ周波数ジッタの割合が多くなるため である，従って，位相差測定の分解能を向上させるために採用し

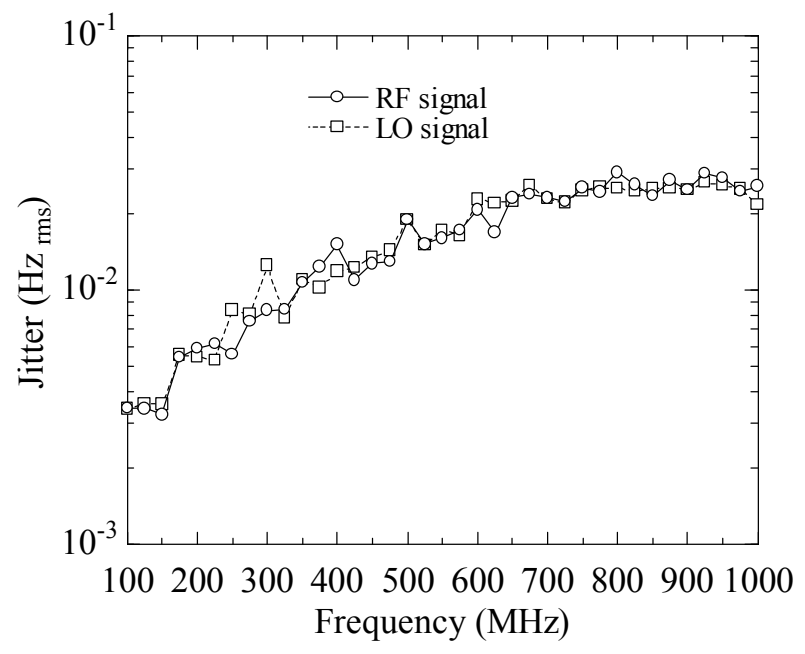

Fig. 3 Measured jitter of a radio frequency signal source and local oscillator signal source.

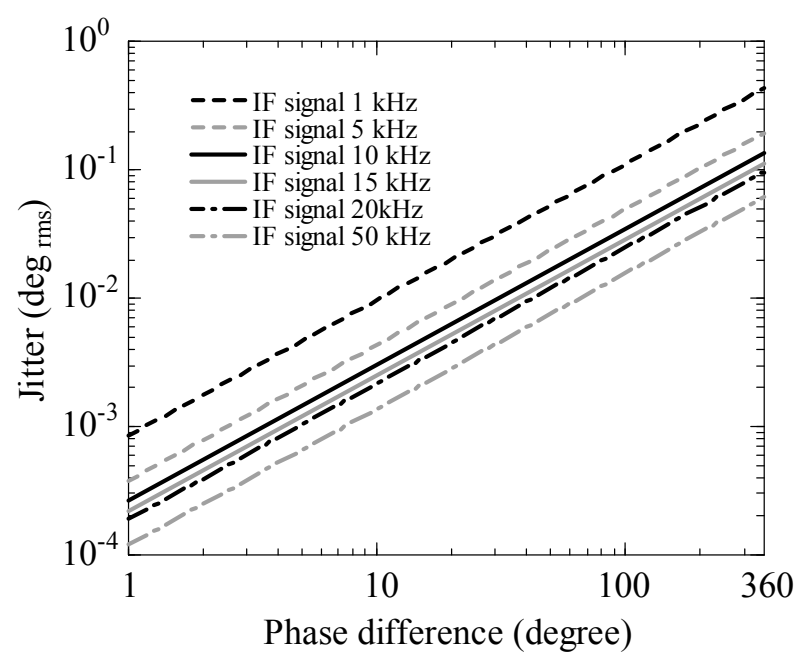

Fig. 4 Phase difference jitter error calculated from the intermediate frequency signal jitter.

た DMTD 方法を使用するときに，極端に IF 信号を低周波に変換 することは，位相差ジッタエラーが増加する原因となることがわ かる.

\section{3 最適な IF 信号の周波数の予測}

$f_{\mathrm{RF}}-f_{\mathrm{LO}}$ 周波数成分以外の不要な周波数成分を発生しない理想 的なミキサを使用した場合に, 信号源固有の周波数ジッタから予 測される位相差ジッタエラー $\phi_{\mathrm{IF}-\mathrm{jitter}}$ とタイムインターバルアナラ イザの内部ジッタエラーによる位相差ジッタエラー $\phi_{\mathrm{int}-\mathrm{jitter}}$ は次式 の関係で加算される.

$$
\phi_{\text {jitter }}=\left(\phi_{\text {IF-jitter }}{ }^{2}+\phi_{\text {int-jitter }}{ }^{2}\right)^{1 / 2}
$$

但し，ここで得られる位相差ジッタエラーは，1 サンプル当たり に現れる位相差ジッタエラーであり, サンプリングレートを考慮 していない，つまり，位相差ジッタエラーが大きくてもサンプリ ングレートが高ければ算術平均により確率誤差は低下することを 


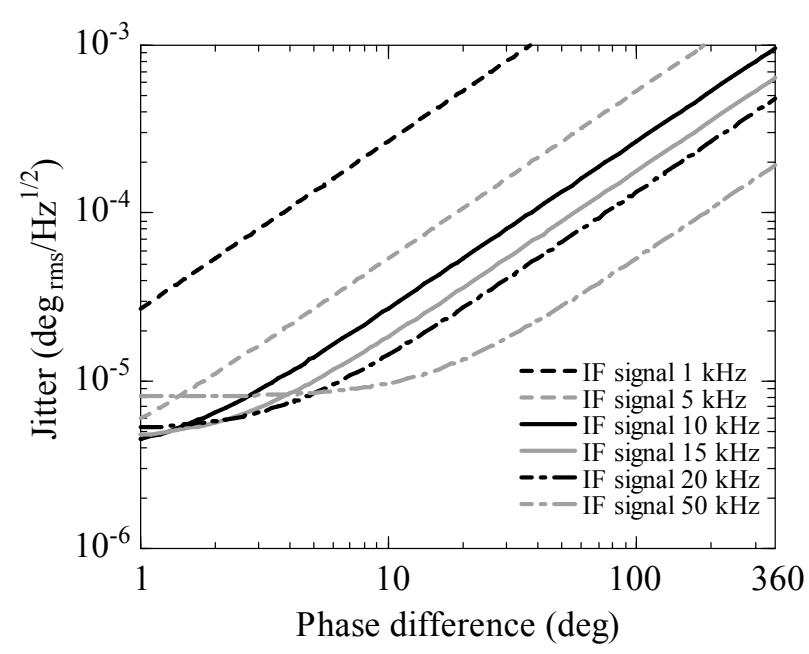

Fig. 5 Phase difference jitter error calculated from the intermediate frequency signal jitter and the internal jitter error of the Time Interval Analyzer.

考慮していない，そのためにサンプリングレートを考慮して位相 差ジッタエラーを評価するには，次式を用いる.

$$
\phi_{\text {jitter }}=\left(\phi_{\mathrm{IF}-\text { jitter }}^{2}+\phi_{\text {int - jitter }}^{2}\right)^{1 / 2} / f_{\mathrm{IF}}^{1 / 2}
$$

(6)式における位相差ジッタエラー $\phi_{\mathrm{jitter}}$ の単位は $\mathrm{deg}_{\mathrm{rms}} / \mathrm{Hz}^{1 / 2}$ と なる．また， $f_{\mathrm{IF}}$ は $\mathrm{IF}$ 信号の周波数であるが，連続サンプリングを 行なうので, IF 信号の周波数 $f_{\mathrm{IF}}$ は位相差測定のサンプリングレー トに等しい. (6)式を用いて計算した結果を Fig. 5 に示寸.

位相差が大きい場合，信号源固有の周波数ジッタによる位相差 ジッタエラーの影響が優先的に現れるために，IF 信号の周波数が 大さいほど位相差ジッタエラーが小さくなることがわかる．位相 差が小さい場合は，信号源固有の周波数ジッタによる位相差ジッ タエラーの影響が減少して, 位相差測定の分解能が向上すること が確認できるが，タイムインターバルアナライザの内部ジッタエ ラーの影響により，位相差ジッタエラーが一定の值に収束するよ うになる，従って，位相差を極力小さくした状態で位相差の測定 を行なえば, 位相差測定分解が優れていることがわかる. しかし， 極端に位相差 $\phi$ を小さくして位相差測定を行なうと，位相差の測 定範囲が士 $\phi$ の範囲内に限定されてしまうために, 交流磁界測定時 におけるダイナミックレンジを低下させる問題が生じる. ここで は, 位相差 $1 \mathrm{deg}$ の測定時を仮定して考察する. 位相差 $1 \mathrm{deg}$ の測 定時の場合，最も位相差ジッタエラーを少なく測定できる最適な IF 信号の周波数は, $10 \mathrm{kHz}$ から $15 \mathrm{kHz}$ 程度であることが予測さ れた.

\section{4 実測による最適なフィルタ設定の検証}

理想的なミキサは $f_{\mathrm{RF}}-f_{\mathrm{LO}}$ 周波数成分以外の不要な周波数成分 を発生しないが, 実際のミキサは僅かながらも $\left|n \times f_{\mathrm{RF}} \pm m \times f_{\mathrm{LO}}\right|$ の信号 ( $m$ と $n$ は任意の正の整数 $)$ の周波数成分を生成する. ま た, Fig. 1 に見られるように, ミキサの出力を増幅するためにアン プを導入しており，アンプの導入によってもランダムな振幅ノイ

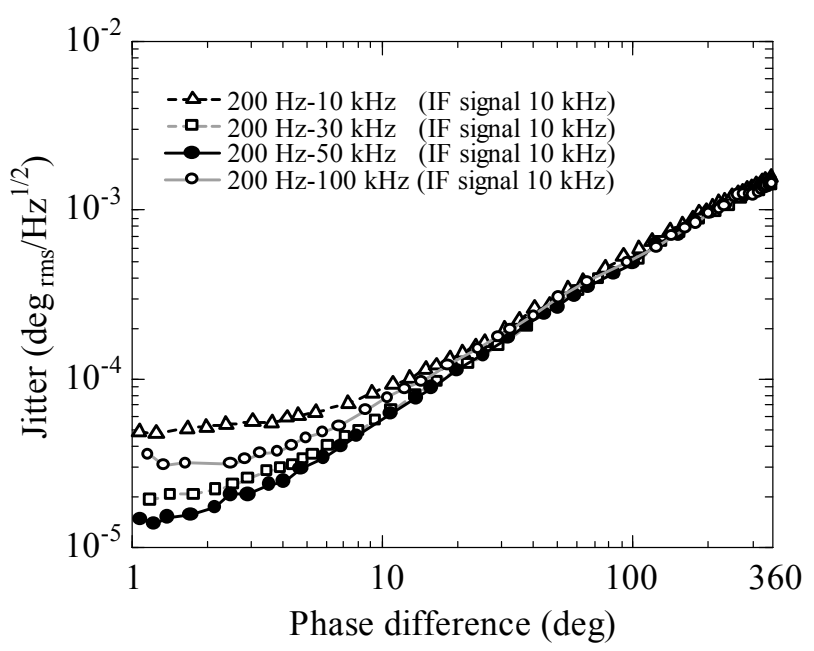

Fig. 6 Dependence on the cutoff frequency of the bandpass filter.

ズが生成される，これらの不要な周波数成分やノイズは，時間差 測定エラーを生じる原因となるトリガータイミングエラーを引き 起こす原因となるために $f_{\mathrm{RF}}-f_{\mathrm{LO}}$ 周波数成分を通過帯域としたバ ンドパスフィルタを使用して除去する必要がある. しかし, 急峻 な通過帯域を持つバンドパスフィルタは周波数に対して急峻に位 相が変化する特性を有しているので，IF 信号の僅かな周波数ジッ タの影響で位相変動を引き起こす原因になると考えられる. した がって, 不要な周波数成分を除去しつつ, 大きな位相変動を引き 起こさない最適なバンドパスフィルタの通過帯域の設定を検証す る必要がある. そこで Fig. 1 における高周波キャリア型薄膜磁界 センサ部分を取り除いた状態で, 最も位相差ジッタエラーが少な くなることが予想される $10 \mathrm{kHz}$ に IF 信号の周波数を固定して, $200 \mathrm{~Hz}-10 \mathrm{kHz}, 200 \mathrm{~Hz}-30 \mathrm{kHz}, 200 \mathrm{~Hz}-50 \mathrm{kHz}, 200 \mathrm{~Hz}-100 \mathrm{kHz}$ の 4 種類の通過帯域を持つバンドパスフィルタで信号処理を行な ったときの位相差-位相差ジッタエラー特性を測定した. ここで, 使用したバンドパスフィルタは 4 次バタワース特性であり, 低周 波側のカットオフ周波数は, 商用周波数の $50 \mathrm{~Hz}$ とその 2 次高調 波を除去できるように $200 \mathrm{~Hz}$ 固定としている. また, RF信号は $500 \mathrm{MHz}, 14 \mathrm{dBm}$ で固定, LO 信号源は $19 \mathrm{dBm}$ 一定として, ミ キサに規定されているLO portのドライブレベルの電力を与えた. また，ミキサの IF 端子に接続されているアンプでは, バンドパス フィルタの入力電圧範囲土 $10 \mathrm{~V}$ に合うように IF 信号を増幅させ た. 位相差-位相差ジッタエラーのバンドパスフィルタの通過帯域 による依存性の測定結果を Fig. 6 に示寸. また, 使用したバンド パスフィルタの位相特性を Fig. 7 に示す.

通過帯域が $200 \mathrm{~Hz}-10 \mathrm{kHz}$ の場合は, カットオフ周波数と IF 信号の周波数が等しいために $f_{\mathrm{RF}}-f_{\mathrm{LO}}$ 周波数成分以外の不要な高 調波成分は除去されるので, $f_{\mathrm{RF}}-f_{\mathrm{LO}}$ 周波数成分だけを含む理想 に近いIF 信号に処理される. しかし，Fig. 7 で確認できるように IF 信号の周波数とカットオフ周波数が等しい場合, フィルタの周 波数-位相特性が最も急峻に変化するので, IF 信号に含まれている 周波数ジッタにより位相の変動が最も大きく生じやすい設定にな 


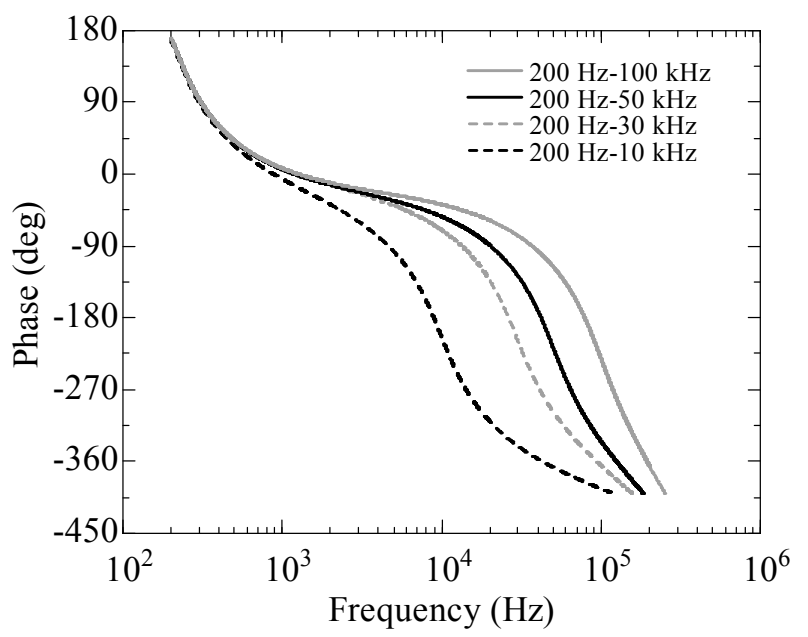

Fig. 7 Measured phase characteristic of the bandpass filter.

る. そのために, Fig. 6 で確認できるようにカットオフ周波数を IF信号より高周波側に設定した $200 \mathrm{~Hz}-30 \mathrm{kHz}$ のバンドパスフィ ルタや $200 \mathrm{~Hz}-50 \mathrm{kHz}$ のバンドパスフィルタで信号処理をしたと きよりも $200 \mathrm{~Hz}-10 \mathrm{kHz}$ のバンドパスフィルタ使用時の位相差ジ ッタエラーは大きくなる.

IF 信号の周波数 $10 \mathrm{kHz}$ を通過帯域が $200 \mathrm{~Hz}-100 \mathrm{kHz}$ のバン ドパスフィルタで信号処理した場合は, Fig. 7 で確認できるように $10 \mathrm{kHz}$ 時のバンドパスフィルタの周波数-位相特性が 4 種類のフ イルタの中で最も緩やかな特性を有しているので，IF 信号に含ま れている周波数ジッタにより位相の変動が発生しにくい設定にな る. しかし, 通過帯域が広くなるので, $f_{\mathrm{RF}}-f_{\mathrm{LO}}$ 周波数成分以外 の不要な周波数成分が含まれた $\mathrm{IF}$ 信号が生成されて, 位相差ジッ タエラーが増える結果となる. したがって, Fig. 6 で確認できるよ うに $200 \mathrm{~Hz}-30 \mathrm{kHz}$ や200 Hz-50 kHzの通過帯域を有するバンド パスフィルタで信号処理をしたときより $200 \mathrm{~Hz}-10 \mathrm{kHz}$ のバンド パスフィルタ使用時の位相差ジッタエラーは大きくなる.

次に, 通過帯域が各々 $200 \mathrm{~Hz}-10 \mathrm{kHz}, 200 \mathrm{~Hz}-30 \mathrm{kHz}$, $200 \mathrm{~Hz}-50 \mathrm{kHz}, 200 \mathrm{~Hz}-100 \mathrm{kHz}$ の特性を持つ 4 種類のバンドパ スフィルタに, 通過帯域範囲内で IF 信号の周波数を変化させたと きの得られる位相差ジッタエラーの最小值のみをまとめたものを Fig. 8 に示す.

Fig. 8 で確認できるように IF 信号の周波数が高い場合は， 3.1 章で予測していたようにタイムインターバルアナライザの内部ジ ッタエラーの影響で位相差ジッタが多くなる．また， IF 信号の周 波数が低い場合は, 3.2 章にて予測していたように信号源の周波数 ジッタの影響で位相差ジッタエラーが増加している傾向がわかる. 更に, バンドパスフィルタの高域カットオフ周波数と IF 信号の周 波数が近い場合，IF 信号の周波数ジッタとフィルタの位相特性か ら位相差ジッタエラーが増加する傾向が確認できる. Fig. 8 により 位相差ジッタエラーが最も小さいの条件は，IF 信号の周波数を $15 \mathrm{kHz}$ に設定して, $200 \mathrm{~Hz}-50 \mathrm{kHz}$ の通過帯域を持つバンドパス フィルタを通過させるときであり，そのときの最小ジッタエラー の值は $1.18 \times 10^{-5} \mathrm{deg}_{\mathrm{rms}} / \mathrm{Hz}^{1 / 2}$ を得た. 予測值と実測值を比較す

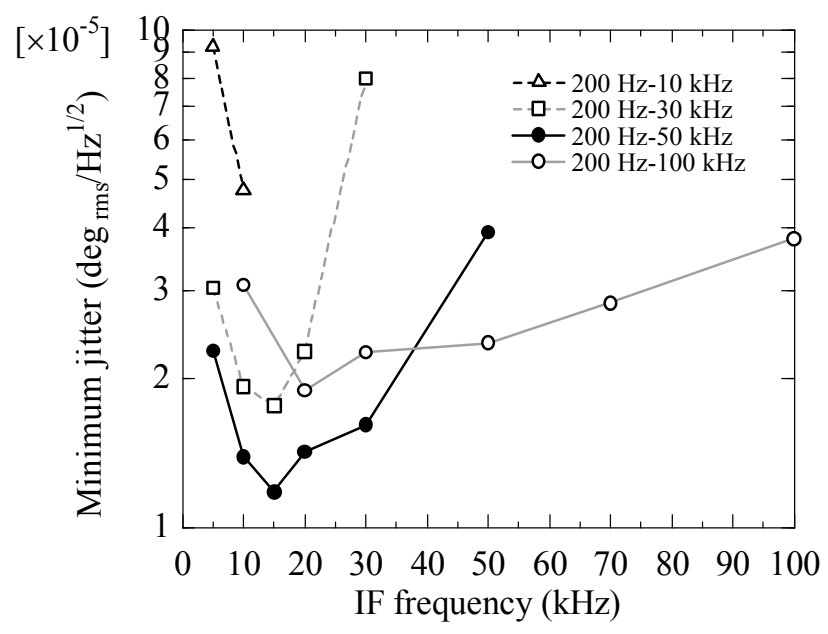

Fig. 8 Minimum phase difference jitter error.

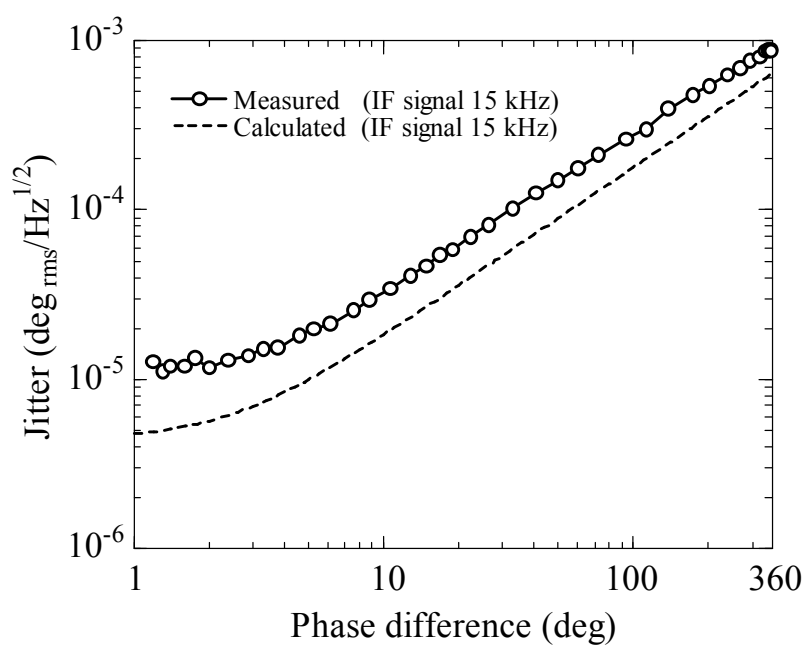

Fig. 9 Measured phase difference jitter error and calculated value.

るために, この最適条件下における位相差-位相差ジッタエラーの 実測值と 3.3 章で得られる予測值を重ねた結果を Fig. 9 に示す.

予測值と実測值を比較すると, 実測值の方が全体的に位相差ジ ッタエラーが多く, 位相差が $1 \mathrm{deg}$ 時における予測值は $4.49 \times 10^{-6} \mathrm{deg} \mathrm{rms} / \mathrm{Hz}^{1 / 2}$ であるのに対して, 実測值は $1.18 \times 10^{-5} \mathrm{deg}_{\mathrm{rms}} / \mathrm{Hz}^{1 / 2}$ であり, 2.6 倍の格差がある. これは, 予 測值では $f_{\mathrm{RF}}-f_{\mathrm{LO}}$ 周波数以外の不要な周波数成分を全く生成しな い理想的なミキサを仮定しており, 実際のDMTD 方法で使用され ているアンプとバンドパスフィルタ, コンパレータによるノイズ 増加の影響を考慮していないためである. また, 実際のDMTD 方 法ではミキサとアンプ, バンドパスフィルタ, コンパレータが 2 組ずつ使用されているが，それらの位相特性が完全に同じである ことはないので, 予測值よりも位相差ジッタエラーを増加させる 原因となる. しかし, 予測值と実測值の位相差ジッタエラーの特 性は酷似しており, 本論文で開発された DMTD 方法による位相差 測定装置は，信号源とタイムインターバルアナライザの仕様から 決定される測定能力の限界を概ね達成していると考えられる. 


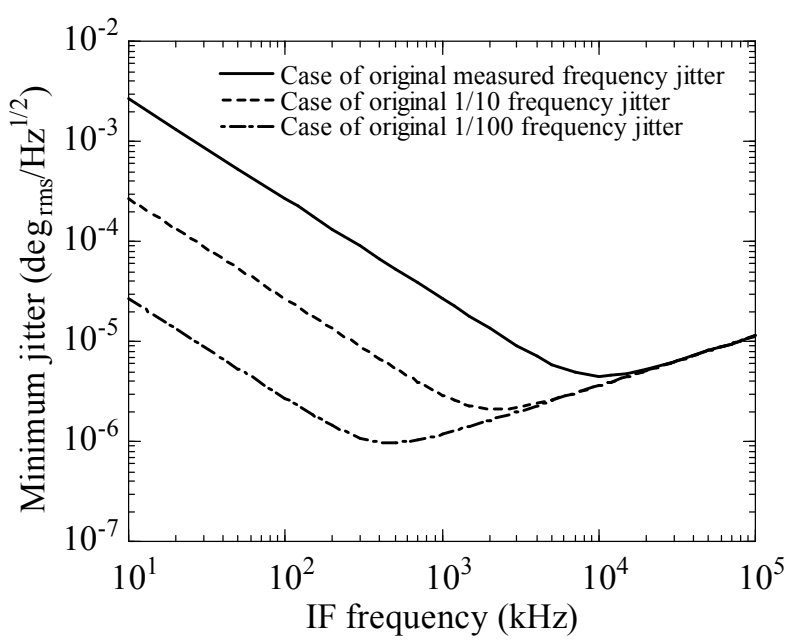

Fig. 10 Minimum phase difference jitter error calculated from the signal source frequency jitter.

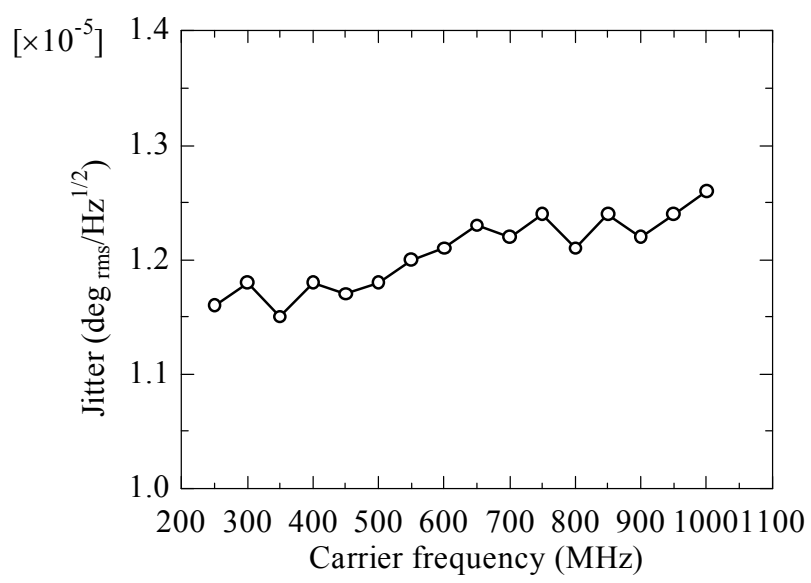

Fig. 11 Measured minimum phase difference jitter error of the phase difference measurement system.

\section{5 位相差測定条件の最適化のまとめ}

更に位相差ジッタエラーを減少させて位相差測定分解能を向上 させる方法としては，安定性の高い信号源を採用して周波数ジッ 夕を減少させる方法が考えられる. 安定性の高い信号源を採用す ることで現状の信号源よりも周波数ジッタを 10 分の 1 と 100 分の 1 に減少できたと仮定した場合において, 位相差が $1 \mathrm{deg}$ 時の位相 差ジッタエラーについてまとめたものを Fig. 10 に示す. IF信号 の周波数が $10 \mathrm{kHz}$ 以上の場合は位相差ジッタエラーがほとんど 同じ值を示し，信号源の安定性を改善しても位相差測定の分解能 が改善しないことがわかる.これは，タイムインターバルアナラ イザの内部ジッタエラーによる測定分解能の影響が大半を占めて いるためである. IF 信号が $1 \mathrm{kHz}$ 程度まで低くなると, タイムイ ンターバルアナライザの内部ジッタエラーにより制限される測定 分解能の影響が少なくなり, 信号源の周波数ジッタ減少の効果が 反映されて，発生する位相差ジッタエラーも減少することがわか るが，同時に位相差測定のサンプリングレートが低下することに もなる. したがって, サンプリングレートが $10 \mathrm{kHz}$ 程度以上であ る必要性があるアプリケーションに応用する場合, 例えば $1 \mathrm{kHz}$

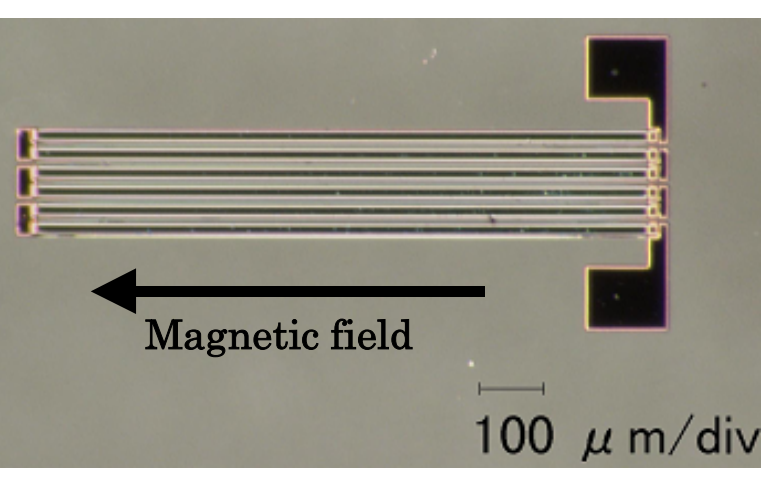

Fig. 12 High-frequency carrier thin film sensor.

程度の交流磁界成分を持つ脳磁界測定に応用する場合を考えてい る場合, 現在使用している信号源よりも安定性の高い信号源を使 用しても，これ以上の位相差測定分解能を得ることはできないと いうことがわかる. したがって, $1 \mathrm{kHz}$ 程度の交流磁界成分の測 定を行なう場合には, 現在の位相差測定装置の持つ測定分解能が 限界性能であることがわかる.

Fig. 11 は, 高周波キャリア型薄膜磁界センサに通電させるキャ リアに相当する RF 信号の周波数を $250 \mathrm{MHz}$ から $1000 \mathrm{MHz}$ ま で変化させたときの位相差ジッタエラーの最小值をまとめたもの である. DMTD 方法の条件は，先に最適な結果を得た IF 信号の 周波数を $15 \mathrm{kHz}$ に設定, $200 \mathrm{~Hz}-50 \mathrm{kHz}$ の通過帯域を持つバン ドパスフィルタを通過させる条件とした. Fig. 3 にみられるように 信号源の周波数が高くなると僅かに周波数ジッタが増える傾向に あるので, Fig. 11 で示される位相差ジッタエラーの最小值も RF 信号の周波数が $250 \mathrm{MHz}$ から $1000 \mathrm{MHz}$ に变化すると, 位相差 ジッタエラーは1.16 $\times 10^{-5} \mathrm{deg}_{\mathrm{rms}} / \mathrm{Hz}^{1 / 2}$ から $1.26 \times 10^{-5} \mathrm{deg}_{\mathrm{rms}} / \mathrm{Hz}^{1 / 2}$ へ僅かに増加する結果を得た。

\section{4. 位相差測定による交流磁界測定}

最適化された DMTD 方法による連続サンプリング位相差測定 装置に高周波キャリア型薄膜磁界センサを導入して交流磁界の測 定を行なった. 使用した高周波キャリア型薄膜センサ 2) の写真を Fig. 12 に示寸. CoNbZr 薄膜を RF スパッタリングにより成膜し ている，センサのパターンは，リフトオフプロセスにより作成し た. 磁化容易軸は, 熱処理により短冊軸方向へ付与した. センサ の寸法は, 長さ $1 \mathrm{~mm}$, 幅 $20 \mu \mathrm{m}$, 膜厚 $4.1 \mu \mathrm{m}$ の 3 ターンで構成 されるミアンダーパターンである. ネットワークアナライザを使 用して, この高周波キャリア型薄膜センサに $500 \mathrm{MHz}$ のキャリア (RF 信号)を通電したときの直流磁界に対するインピーダンス特性 と DMTD 方法を用いて測定した位相差特性をまとめて Fig. 13 に 示す. 交流磁界測定は, $500 \mathrm{MHz}$ のキャリア(RF 信号)を通電して, $8 \mathrm{Oe}$ の直流バイアス磁界を加えて位相差変化率が $1.90 \mathrm{deg} / \mathrm{Oe}$ に なるように調整した. このときの DMTD 方法は, 最適条件下(IF 信号の周波数は $15 \mathrm{kHz}$ ，バンドパスフィルタの通過帯域は $200 \mathrm{~Hz}-50 \mathrm{kHz}$, アンプはバンドパスフィルタの入力電王範囲の $\pm 10 \mathrm{~V}$ に増幅, 位相差測定のサンプリングレートは $15 \mathrm{kHz}$ )に設 


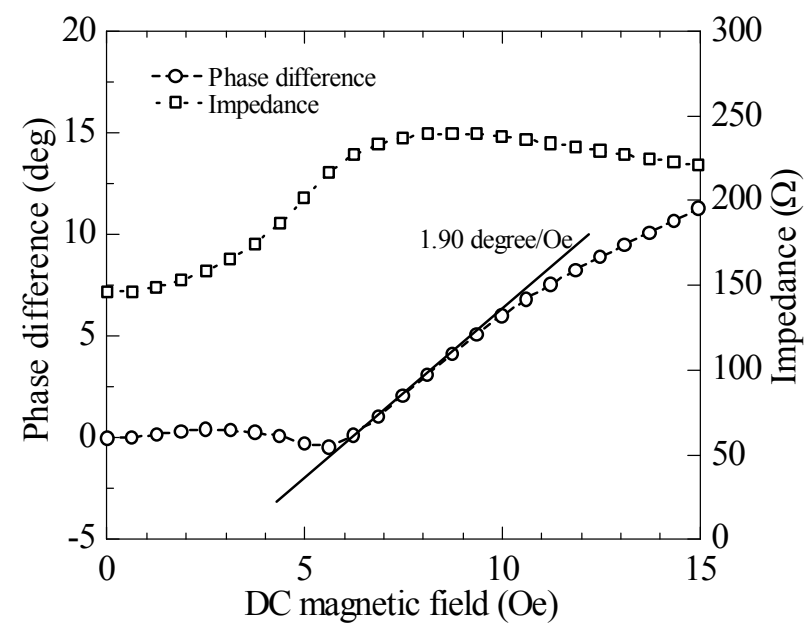

Fig. 13 Relationship of the dc magnetic field to the phase difference and the impedance of the sensor at a carrier frequency of $500 \mathrm{MHz}$.

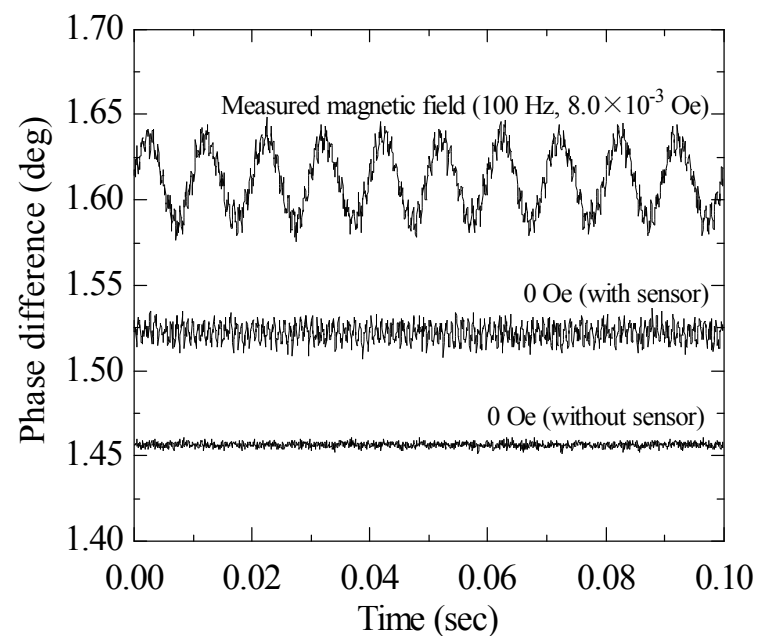

Fig. 14 Measured ac magnetic field and phase difference fluctuations.

定している．また位相差測定による磁界測定の実験は，磁気シー ルドルーム内で行なわれた. これらの条件下で高周波キャリア型 薄膜磁界センサに $8.0 \times 10^{-3} \mathrm{Oe}$ の交流磁界を加えた場合と交流磁 界を加えない場合，更に高周波キャリア型薄膜磁界センサを取り 外した場合の各々の位相差測定結果をまとめて Fig. 14 に示す.

Fig. 14 で見られるように，開発された連続サンプリング位相差 測定装置を使用することで，位相差測定による交流磁界測定が実 現できた. また高周波キャリア型薄膜磁界センサを取り付けたと きの位相差ジッタエラーは $3.23 \times 10^{-5} \mathrm{deg}_{\mathrm{rms}} / \mathrm{Hz}^{1 / 2}$ であり, 取り 付ける前のキャリア $500 \mathrm{MHz}$ 時の位相差ジッタエラー $1.18 \times 10^{-5} \mathrm{deg}_{\mathrm{rms}} / \mathrm{Hz}^{1 / 2}$ に比較して 2.7 倍程度に増加しており $\mathrm{S} / \mathrm{N}$ 比を悪化させていることがわかった．また，交流磁界測定時 にも同じく増加した位相差ジッタエラーが混在していることが確 認できる.このときの高周波キャリア型薄膜磁界センサの位相差 変化率と増加した位相差ジッタエラーの比率を考慮すると, 磁界 測定の分解能は $1.7 \times 10^{-5} \mathrm{Oe} / \mathrm{Hz}^{1 / 2}$ と見積もられる.

今後の高分解能化を考慮すると, センサを接続することにより
位相差ジッタエラーが増えないセンサ構造が必要である．使用し たセンサは，振幅変調用の設計であるので集中定数回路素子とし てのインピーダンスの変化量を重視したものであり，Fig. 13 によ ると位相差測定による磁界測定を行なったときのインピーダンス

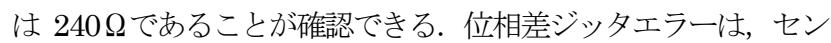
サを取り付けた時点で増加していることから，センサの有するイ ンピーダンス $240 \Omega$ にる特性インピーダンス不整合による多重 反射が位相差ジッタエラー増加の原因と考えられる. 開発した位 相差測定装置の性能を十分に引き出しながら磁界測定分解能を向 上させるには，位相の変化率を重視した磁界センサを開発すると 同時に, 特性インピーダンスの整合性を考慮したセンサ構造が必 要である.

\section{5. まとめ}

DMTD 方法で位相差を連続サンプリングするときの最適な条 件を検討した. その結果, $15 \mathrm{kHz}$ のサンプリングレートで $250 \mathrm{MHz}$ から $1000 \mathrm{MHz}$ までの高周波で生じる位相差を $1.16-1.26 \times 10^{-5} \mathrm{deg}_{\mathrm{rms}} / \mathrm{Hz}^{1 / 2}$ の高分解能で連続測定可能な位相 差測定装置を開発した。

開発された連続サンプリング位相差測定装置を使用することで, 高周波キャリア型薄膜磁界センサの位相差変化を $15 \mathrm{kHz}$ でサン プリングすることが可能となり, 直流から $1 \mathrm{kHz}$ 程度までの低周 波交流磁界測定が可能となった.

\section{謝辞}

本研究の DMTD 法の開発に際して有意義なご助言を頂きまし た独立行政法人産業技術総合研究所の今江理人氏，ならびに独立 行政法人情報通信研究機構の森川容雄氏, 花土ゆう子氏に謝意申 し上げます．本研究の一部は文部科学省科学研究費補助金基盤研 究A（採択番号 16206041）, ならびに東北大学 21 世紀 COE プ ログラム「新世代情報エレクトロニクスシステムの構築」により 行なったものである.

\section{Reference}

1) S. Yabukami, T. Suzuki, N. Ajiro, H. Kikuchi, M. Yamaguchi, and K.I. Arai, IEEE Trans. Magn., vol. 37, p2019-2021, 2001.

2) H. Mawatari, H. Kikuchi, S. Yabukami, M. Yamaguchi, and K.I. Arai, J. Magn. Soc. Jpn., vol. 27, p414-418, 2003.

3) Allan, D. W.; "The measurement of frequency and frequency stability of precision oscillators", NBS Tech. Note 699, May 1975.

4) Allan, D. W. and Daams, H.; "Picosecond time difference measurement system", Proc. 29th Annu. Symp. Frequency Control, pp.404-411, May 1975.

5) T. Ozawa, H. Mawatari, Y. Murayama, S. Yabukami, K.I. Arai, Y. Hanado, and M. Imae, J. Magn. Soc. Jpn., vol. 28, p718-721, 2004.

2004 年 10 月 5 日受理, 2005 年 6 月 10 日採録 